ORIGINAL ARTICLE

\title{
胸部悪性腫瘍に関するセカンドオピニオンの現状
}

\author{
東山量子 1,2 ・吉田達哉 1 ・白澤昌之 1 ・荒川さやか 1 新野祐樹 1 ・ \\ 大熊裕介 $1 \cdot$ 後藤 $\quad$ 悌 $1 \cdot$ 堀之内秀仁 $1 \cdot$ 山本 $\quad$ 昇 $1 \cdot$ 大江裕一郎 1,2
}

\section{Current Status Concerning the Retention of a Second Opinion in Patients with Thoracic Malignancies}

Ryoko Inaba Higashiyama1,2; Tatsuya Yoshida1; Masayuki Shirasawa1; Sayaka Arakawa1; Yuki Shinno1; Yusuke Okuma1; Yasushi Goto1; Hidehito Horinouchi1; Noboru Yamamoto1; Yuichiro Ohe1,2

${ }^{1}$ Department of Thoracic Oncology, National Cancer Center Hospital, Japan; ${ }^{2}$ Course of Advanced Clinical Research of Cancer, Juntendo University Graduate School of Medicine, Japan.

ABSTRACT - Objective. A second opinion has potential advantages of leading to the appropriate diagnosis and treatment plan for patients with cancer and medical oncologist. However, whether or not the second opinion influences the diagnosis and treatment policy of patients with thoracic malignancies remains unclear. Methods. We retrospectively investigated patients with thoracic malignancies who asked for a second opinion at the National Cancer Center Hospital in 2019. Results. A total of 540 patients asked for a second opinion, including 341 (63.1\%) patients with non-small-cell lung cancer, 38 (7.0\%) patients with small-cell lung cancer, 68 (12.6\%) patients with thymic epithelial tumor, $16(3.0 \%)$ patients with pleural mesothelioma, and 77 (14.3\%) patients with other thoracic malignancies. Different treatment advice from that received at the referring hospital was received by 147 (27.2\%) patients at the second opinion. The details concerning the proposed treatment policies included a change in the chemotherapy regimen in 51 (34.7\%) patients, a change to best supportive care (BSC) in 28 (19.0\%) patients, a change from BSC to chemotherapy in $24(16.3 \%)$ patients, and a change to surgery in $12(8.2 \%)$ patients. Conclusion. The second opinion can result in different treatment advice, including curable treatments, such as surgery, for patients with thoracic malignancies.

(JJLC. 2021;61:939-945)

KEY WORDS — Thoracic malignancy, Lung cancer, Second opinion, Designated cancer hospital

Corresponding author: Tatsuya Yoshida.

Received July 1, 2021; accepted August 5, 2021.

要旨一一目的. セカンドオピニオン $(\mathrm{SO})$ は，患者や主 治医が診断や治療方針の決定に苦慮する際にそれらを決 定するための重要な手段となり得る。本研究では胸部悪 性腫瘍患者における SO の現状と意義について検討し た. 方法. 2019 年に国立がん研究センター中央病院呼吸 器内科の SO 外来に受診した胸部悪性腫瘍またはその疑 い患者を対象として，患者背景・SO 内容などについて 後方視的に調査した。結果. 上記期間中にのべ 540 人が SO 外来に受診した。非小細胞肺癌が 341 人 (63.1\%)，小 細胞肺癌が 38 人 $(7.0 \%)$, 胸腺上皮性腫瘍が 68 人
$(12.6 \%)$ ，胸膜中皮腫が 16 人 $(3.0 \%)$ ，その他が 77 人 (14.3\%)であった.SO で主治医の治療方針変更が提案さ れたのが 147 人 $(27.2 \%)$ で，化学療法レジメン変更が 51 人 $(34.7 \%)$, best supportive care (BSC) への変更が 28 人 $(19.0 \%), \mathrm{BSC}$ より化学療法への変更が 24 人 $(16.3 \%)$, 手術可能が 12 人 $(8.2 \%)$ であった．結論．胸部悪性腫瘍 患者への SO により，手術など根治的治療への变更を含 め治療方針変更を提案される症例は少なくない.

索引用語——胸部悪性腫瘍, 肺癌, セカンドオピニオン, がん診療拠点病院
1国立がん研究センター中央病院呼吸器内科 ; 2 順天堂大学大学 院医学系研究科がん先端臨床研究コース.
論文責任者：吉田達哉

受付日： 2021 年 7 月 1 日, 採択日：2021 年 8 月 5 日。 


\section{目 的}

セカンドオピニオンは, 主治医から提示された疾患の 診断および治療方針について，主治医以外の第三者の専 門医が提示する医療上の意見のことであり，患者や主治 医が診断や治療方針の決定に悩む際に，それらを決定す るための重要な手段となり得る.1,2 またセカンドオピニ オンは，意図せずとも紹介元の治療方針が他施設からの 批判的吟味の対象となり, 医療者側としては自施設の診 断，治療方針の妥当性の確認などができるとともに，患 者側としては病態や治療方針の理解や納得度が深まるな ど，非常に有用な医療行為の一つである.

乳癌領域においては, セカンドオピニオンを行った 16.4 25.1\%の患者で，主治医の治療方針とセカンドオ ピニオンでの治療方針が異なっていたとの報告があ る1,3,4が, 肺癌をはじめとした胸部悪性腫瘍に関する報告 はない.

本研究では, 胸部悪性腫瘍患者におけるセカンドオピ ニオンの現状と意義について検討した.

\section{方 法}

2019 年 1 月から 12 月までに国立がん研究センター中 央病院呼吸器内科のセカンドオピニオン外来に受診した 胸部悪性腫瘍またはその疑い患者を対象として, 患者背 景, 受診者 (本人, 家族など), 紹介元病院の種類 (がん 診療連携拠点病院 [がん拠点病院 $]$, がん拠点病院以外,
海外), 受診目的, 紹介元の診断 - 治療方針, 遺伝子変異 の検査の詳細, セカンドオピニオンの内容, セカンドオ ピニオン後の治療場所を，後方視的に調査した.

\section{結 果}

2019 年 1 月から 12 月までにのべ 540 人 (3 回受診した 患者 1 人, 2 回受診した患者 4 人)が, セカンドオピニオ ン外来に受診した，年齢中央值（範囲）は 65 歳（24９5 歳)，男性/女性が $210 / 330$ 人 $(38.9 / 61.1 \%)$ であった。受 診時に，患者本人が来院したのは 398 人 $(73.7 \%)$ で，家 族・親族のみは 142 人 $(26.3 \%)$ であった. Performance Status の内訳 は, 0 1 が 230 人 $(42.6 \%), 2 \sim 3$ が 76 人 $(14.1 \%), 4$ が 12 人 $(2.2 \%), 222$ 人 $(41.1 \%)$ が不明 であった。

胸部悪性腫瘍の内訳としては, 非小細胞肺癌が 341 人 $(63.1 \%) ，$ 小細胞肺癌が 38 人 $(7.0 \%)$, 胸腺上皮性腫瘍が 68 人 $(12.6 \%)$, 悪性胸膜中皮腫が 16 人 $(3.0 \%)$, 他癌種 の転移および原発不明癌, 炎症性線維芽細胞性腫瘍が 26 人 $(4.8 \%)$ ，未診断が 51 人 $(9.4 \%)$ であった。

患者の居住地は, 国立がん研究センター中央病院のあ る関東圈が 418 人 $(77.4 \%)$ と最も多いが, 北海道から沖 縄まで多岐にわたっていた。また海外からの患者は, 中 華人民共和国からが最も多く 28 人（5.2\%）であった.

紹介元病院については, がん拠点病院からの紹介が 347 人 $(64.3 \%)$, がん拠点病院以外からの紹介が 157 人 (29.1\%) であった.

Table 1. Patient Characteristics $(\mathrm{N}=540)$

\begin{tabular}{lc}
\hline & $\mathrm{N}(\%)$ \\
\hline Age, years; median (range) & $65(24-95)$ \\
Sex (female/male) & $330(61.1) / 210(38.9)$ \\
Performance Status (0-1/2-3/4/unknown) & $230(42.6) / 76(14.1) / 12(2.2) / 222(41.1)$ \\
Histology & \\
Non-small-cell lung cancer & $341(63.1)$ \\
Small-cell lung cancer & $38(7.0)$ \\
Thymic epithelial tumor & $68(12.6)$ \\
Malignant pleural mesothelioma & $16(3.0)$ \\
Other malignant tumors & $26(4.8)$ \\
Undiagnosed & $51(9.4)$ \\
Referring hospital (designated cancer hospital/non-designated & $347(64.3) / 157(29.1) / 36(6.7)$ \\
cancer hospital/overseas) & \\
People who want a second opinion & \\
Patient-initiated & $464(85.9)$ \\
Primary physician-initiated & $61(11.3)$ \\
Both (patient/doctor initiated) & $15(2.8)$ \\
Timing of the second opinion & \\
Before initial treatment & $226(41.9)$ \\
During front-line treatment & $154(28.5)$ \\
After second-line treatment & $160(29.6)$ \\
\hline
\end{tabular}


Non-squamous cell lung cancer

$(\mathrm{N}=225)$

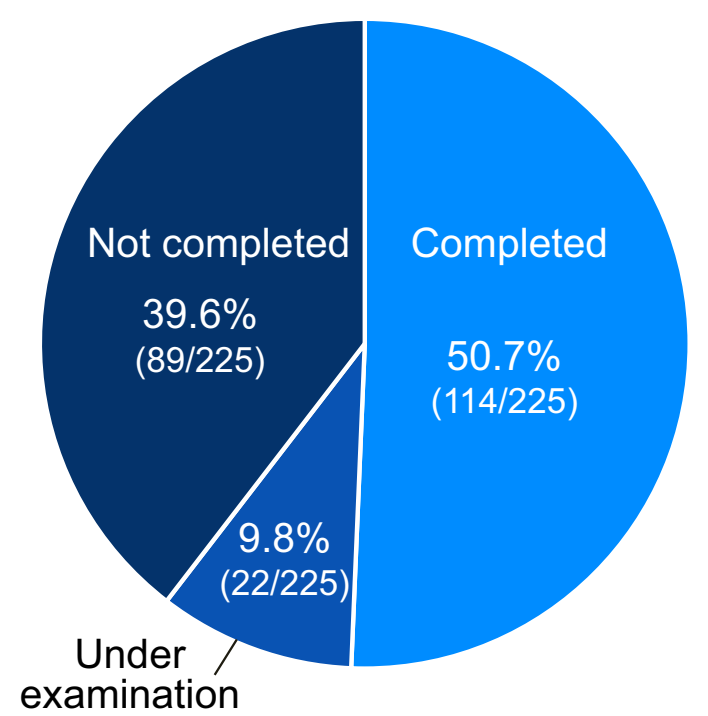

Squamous cell lung cancer $(\mathrm{N}=39)$

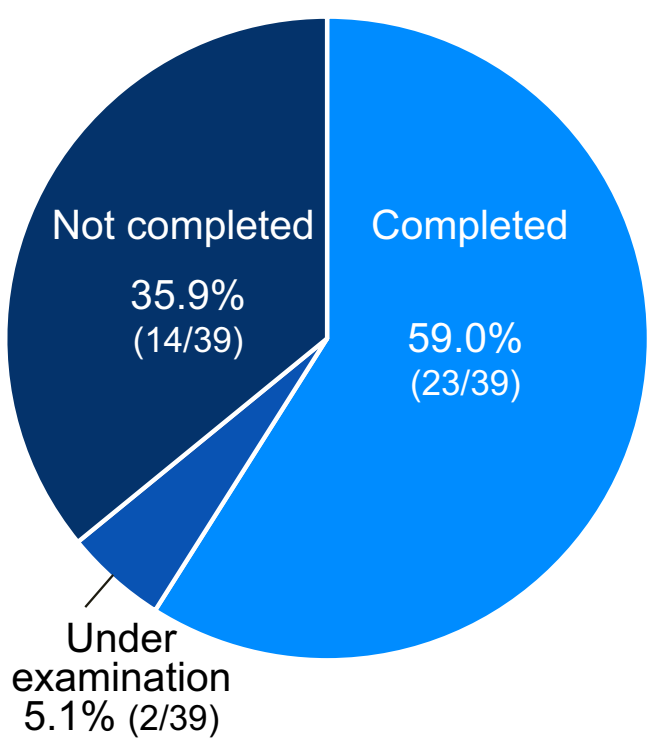

Figure 1. Status of genomic screening test at the second opinion in non-small-cell cancer patients (N $=264)$.

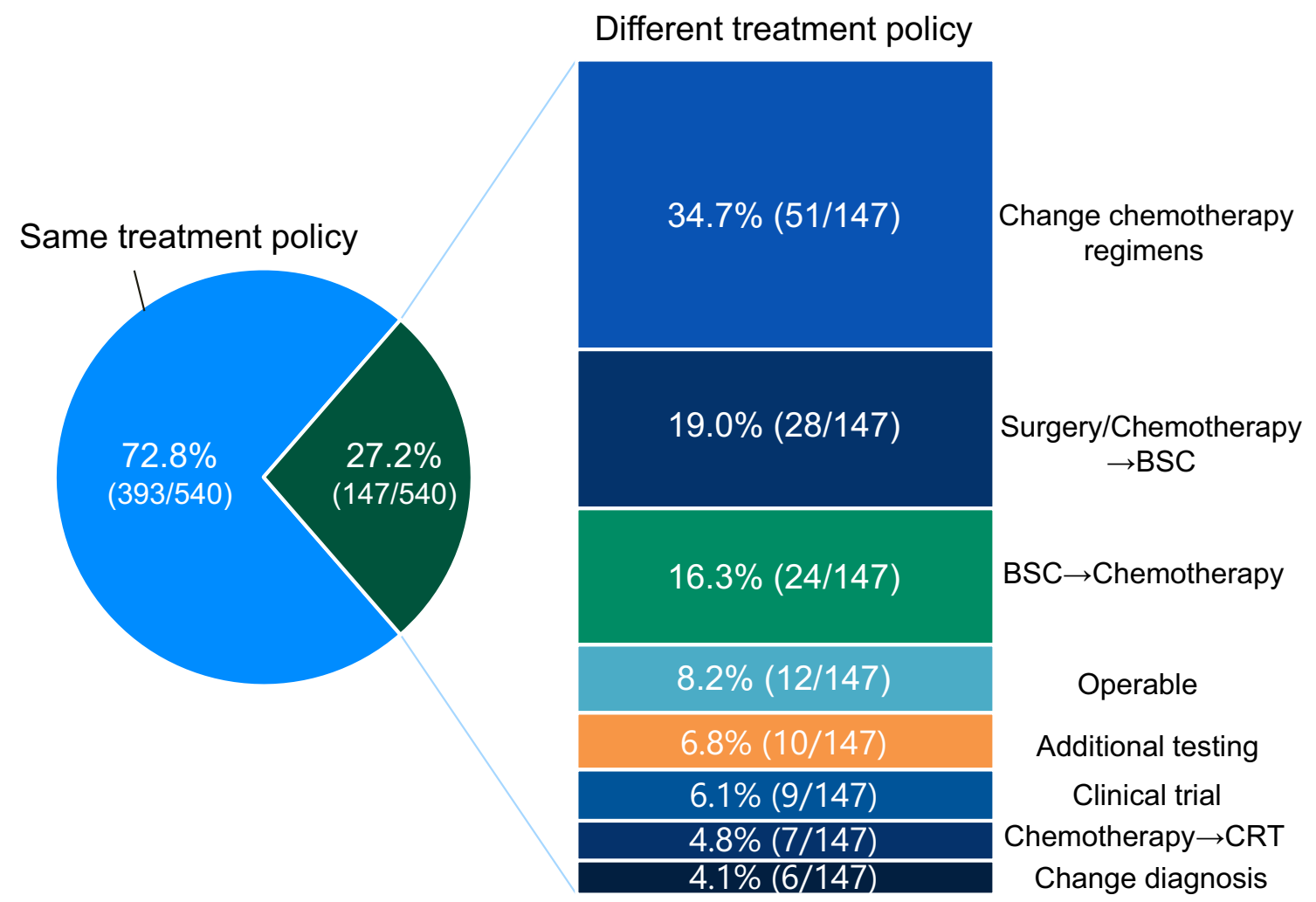

Figure 2. Proposed treatment at the second opinion $(\mathrm{N}=540)$. CRT: chemoradiation therapy. 
Table 2. Details of BSC Cases Judged to Be Eligible for Systemic Therapy at the Second Opinion $(\mathrm{N}=24)$

\begin{tabular}{|c|c|c|c|c|c|c|c|c|c|c|c|c|c|}
\hline \multirow{3}{*}{ Case } & \multirow{3}{*}{$\begin{array}{c}\text { Age } \\
\text { (years) }\end{array}$} & \multirow{3}{*}{ Sex } & \multirow[b]{3}{*}{$\begin{array}{l}\text { Can- } \\
\text { cer } \\
\text { type }\end{array}$} & \multicolumn{5}{|c|}{ Referral hospital } & \multirow{2}{*}{\multicolumn{2}{|c|}{$\begin{array}{l}\text { Second } \\
\text { opinion }\end{array}$}} & \multirow{3}{*}{$\begin{array}{l}\text { Trans- } \\
\text { ferred }\end{array}$} & \multirow{3}{*}{$\begin{array}{c}\text { Actual } \\
\text { treatment }\end{array}$} & \multirow{3}{*}{$\begin{array}{r}\text { Overall } \\
\text { survival }^{*} \\
\text { (months) }\end{array}$} \\
\hline & & & & \multicolumn{4}{|c|}{ Diagnosis } & & & & & & \\
\hline & & & & $\begin{array}{l}\text { Histol- } \\
\text { ogy }\end{array}$ & Stage & PS & Mutation & $\begin{array}{l}\text { Timing } \\
\text { of SO }\end{array}$ & $\begin{array}{l}\text { Reason } \\
\text { for BSC }\end{array}$ & $\begin{array}{l}\text { Treatment } \\
\text { policy }\end{array}$ & & & \\
\hline 1 & 78 & $\mathrm{~F}$ & $\mathrm{LC}$ & $\mathrm{Sq}$ & IVA & 1 & Unknown & 3rd line & Unknown & ICI & Yes & $\begin{array}{l}\text { Nivolum- } \\
\text { ab }\end{array}$ & 1.4 \\
\hline 2 & 67 & $\mathrm{M}$ & TET & $\mathrm{Sq}$ & $\begin{array}{l}\text { Postoperative } \\
\text { recurrence }\end{array}$ & 1 & Unknown & $\begin{array}{l}\text { Before } \\
\text { 1st line }\end{array}$ & $\begin{array}{c}\text { ILD, } \\
\text { IgG4-related } \\
\text { disease }\end{array}$ & $\begin{array}{c}\text { CBDCA }+ \\
\text { PTX }\end{array}$ & Yes & $\begin{array}{l}\text { CBDCA } \\
+ \text { PTX }\end{array}$ & $8.0+$ \\
\hline 3 & 54 & $\mathrm{~F}$ & $\mathrm{LC}$ & Adeno & IVB & 2 & EGFR & $\begin{array}{l}\text { Before } \\
\text { 1st line }\end{array}$ & $\begin{array}{l}\text { Massive pleural } \\
\text { effusion }\end{array}$ & Osimertinib & Yes & $\begin{array}{l}\text { Osimer- } \\
\text { tinib }\end{array}$ & $22.8+$ \\
\hline 4 & 44 & M & LC & Adeno & $\begin{array}{l}\text { Postoperative } \\
\text { recurrence }\end{array}$ & 1 & No & 2nd line & $\begin{array}{c}\text { Poor pain } \\
\text { control }\end{array}$ & ICI or DTX & Yes & $\begin{array}{l}\text { Nivolum- } \\
\text { ab }\end{array}$ & 0.4 \\
\hline 5 & 95 & M & $\mathrm{LC}$ & NOS & IIIA & 0 & No & $\begin{array}{l}\text { Before } \\
\text { 1st line }\end{array}$ & Old age & ICI & Yes & $\begin{array}{l}\text { Pembroli- } \\
\text { zumab }\end{array}$ & $20.6+$ \\
\hline 6 & 73 & $\mathrm{~F}$ & $\mathrm{LC}$ & Adeno & $\begin{array}{l}\text { Postoperative } \\
\text { recurrence }\end{array}$ & 1 & No & 5th line & $\begin{array}{l}\text { No standard } \\
\text { treatment }\end{array}$ & AMR & No & Unknown & Unknown \\
\hline 7 & 86 & M & $\mathrm{LC}$ & $\mathrm{Sq}$ & IVA & Unknown & No & $\begin{array}{l}\text { Before } \\
\text { 1st line }\end{array}$ & $\begin{array}{l}\text { Old age, } \\
\text { chronic renal } \\
\text { failure }\end{array}$ & RT & No & Unknown & Unknown \\
\hline 8 & 56 & M & TET & NET & Masaoka IVa & 0 & Unknown & $\begin{array}{l}\text { Before } \\
\text { 1st line }\end{array}$ & $\begin{array}{l}\text { No standard } \\
\text { treatment }\end{array}$ & Everolimus & No & Unknown & Unknown \\
\hline 9 & 39 & M & PIMT & - & $\begin{array}{l}\text { Incomplete } \\
\text { resection }\end{array}$ & 0 & ALK & $\begin{array}{l}\text { Before } \\
\text { 1st line }\end{array}$ & Unknown & $\begin{array}{l}\text { Chemother- } \\
\text { apy }\end{array}$ & No & Unknown & Unknown \\
\hline 10 & 84 & $\mathrm{~F}$ & LC & Adeno & IVA & 3 & EGFR & $\begin{array}{l}\text { Before } \\
\text { 1st line }\end{array}$ & Poor PS & Osimertinib & No & Unknown & Unknown \\
\hline 11 & 71 & M & $\mathrm{LC}$ & NOS & IVA & 3 & No & 5 th line & Poor PS & ICI & No & wn & Unknown \\
\hline 12 & 81 & M & LC & Sarco & $\begin{array}{l}\text { Postoperative } \\
\text { recurrence }\end{array}$ & 1 & Unknown & $\begin{array}{l}\text { Before } \\
\text { 1st line }\end{array}$ & $\begin{array}{c}\text { No standard } \\
\text { treatment }\end{array}$ & ICI & No & Unknown & Unknown \\
\hline 13 & 87 & M & $\mathrm{LC}$ & Adeno & IVA & 4 & EGFR & 2nd line & $\begin{array}{l}\text { Adverse events } \\
\text { from prior } \\
\text { treatment }\end{array}$ & Osimertinib & No & Unknown & Unknown \\
\hline 14 & 62 & $\mathrm{~F}$ & LC & Adeno & IVA & 0 & $\begin{array}{l}\text { EGFR, } \\
\text { T790M }\end{array}$ & 1st line & $\begin{array}{c}\text { No standard } \\
\text { treatment }\end{array}$ & Osimertinib & No & Unknown & Unknown \\
\hline 15 & 36 & $\mathrm{~F}$ & $\mathrm{LC}$ & SCLC & $\begin{array}{l}\text { Extensive } \\
\text { disease }\end{array}$ & 1 & Unknown & 1st line & Unknown & $\begin{array}{l}\text { Chemother- } \\
\text { apy }\end{array}$ & No & Unknown & Unknown \\
\hline 16 & 54 & $\mathrm{~F}$ & LC & Adeno & IVA & 0 & EGFR & 1st line & $\begin{array}{l}\text { Massive pleural } \\
\text { effusion }\end{array}$ & Osimertinib & No & Unknown & Unknown \\
\hline 17 & 81 & $\mathrm{~F}$ & LC & Adeno & IV A & 1 & EGFR & 3rd line & $\begin{array}{l}\text { Adverse events } \\
\text { from prior } \\
\text { treatment }\end{array}$ & ICI & No & Unknown & Unknown \\
\hline 18 & 53 & $\mathrm{~F}$ & TET & $\mathrm{Sq}$ & Masaoka IVb & 1 & Unknown & 6th line & $\begin{array}{c}\text { No standard } \\
\text { treatment }\end{array}$ & Sunitinib & No & Unknown & Unknown \\
\hline 19 & 65 & $\mathrm{~F}$ & LC & SCLC & $\begin{array}{l}\text { Limited } \\
\text { disease }\end{array}$ & 3 & Unknown & 3rd line & ILD & AMR & No & Unknown & Unknown \\
\hline 20 & 68 & M & TET & $\mathrm{Sq}$ & Masaoka III & Unknown & Unknown & 5th line & $\begin{array}{l}\text { Adverse events } \\
\text { from prior } \\
\text { treatment }\end{array}$ & Sunitinib & No & Unknown & Unknown \\
\hline 21 & 75 & M & LC & Adeno & IVA & 0 & No & $\begin{array}{l}\text { Before } \\
\text { 1st line }\end{array}$ & Unknown & $\begin{array}{c}\text { Chemother- } \\
\text { apy + ICI }\end{array}$ & No & Unknown & Unknown \\
\hline 22 & 83 & M & $\mathrm{LC}$ & Adeno & IV A & 0 & No & $\begin{array}{l}\text { Before } \\
\text { 1st line }\end{array}$ & Old age & $\begin{array}{l}\text { Chemother- } \\
\text { apy + ICI }\end{array}$ & No & Unknown & Unknown \\
\hline 23 & 70 & $\mathrm{M}$ & $\mathrm{LC}$ & Adeno & IV A & 3 & No & 3rd line & Poor PS & ICI & No & Unknown & Unknown \\
\hline 24 & 60 & M & LC & Adeno & IVA & Unknown & No & 3rd line & Unknown & ICI & No & Unknown & Unknown \\
\hline
\end{tabular}

PS: Performance Status, SO: second opinion, BSC: best supportive care, F: female, LC: lung cancer, Sq: squamous cell carcinoma, ICI: immune checkpoint inhibitor, M: male, TET: thymic epithelial tumor, ILD: interstitial lung disease, PIMT: pulmonary inflammatory myofibroblastic tumor, Sarco: sarcomatoid carcinoma, CBDCA: carboplatin, PTX: paclitaxel, EGFR: epidermal growth factor receptor mutation-positive, DTX: docetaxel, NOS: not otherwise specified, AMR: amrubicin, RT: radiation therapy, NET: neuroendocrine, + : ongoing (data cut-off April 30, 2021), * Overall survival: from the date of the first visit to our hospital to the date of death. 
Table 3. Details of Cases Judged to Be Eligible for Surgery at the Second Opinion $(\mathrm{N}=12)$

\begin{tabular}{|c|c|c|c|c|c|c|c|c|c|c|c|c|}
\hline \multirow{3}{*}{ Case } & \multirow{3}{*}{$\begin{array}{c}\text { Age } \\
\text { (years) }\end{array}$} & \multirow{3}{*}{ Sex } & \multirow{2}{*}{\multicolumn{4}{|c|}{ Referral hospital }} & \multirow{3}{*}{$\begin{array}{l}\text { Treatment } \\
\text { policy }\end{array}$} & \multirow{3}{*}{$\begin{array}{l}\text { Second } \\
\text { opinion } \\
\text { Treat- } \\
\text { ment } \\
\text { policy }\end{array}$} & \multirow{3}{*}{$\begin{array}{l}\text { Trans- } \\
\text { ferred }\end{array}$} & \multirow{3}{*}{$\begin{array}{l}\text { Actual treatment } \\
\text { (histology, } \\
\text { pStage) }\end{array}$} & \multirow{3}{*}{$\begin{array}{l}\text { Relapse- } \\
\text { free } \\
\text { survival } \\
\text { (months) }\end{array}$} & \multirow{3}{*}{$\begin{array}{l}\text { Overall } \\
\text { survival } \\
\text { (months) }\end{array}$} \\
\hline & & & & & & & & & & & & \\
\hline & & & $\begin{array}{c}\text { Cancer } \\
\text { type }\end{array}$ & Histology & Stage & Mutation & & & & & & \\
\hline 1 & 79 & M & $\mathrm{LC}$ & $\begin{array}{l}\text { Uncon- } \\
\text { firmed }\end{array}$ & IIIA & Unknown & CCRT & Operable & Yes & $\begin{array}{l}\text { Lobectomy } \\
\text { (pleomorphic, } \\
\text { pStage IIIA) }\end{array}$ & 2.2 & 2.2 \\
\hline 2 & 71 & F & $\mathrm{LC}$ & $\mathrm{Sq}$ & IIIA & Unknown & CCRT & Operable & Yes & $\begin{array}{c}\text { Lobectomy } \\
\text { (Sq, pStage IA1) }\end{array}$ & $22.5+$ & $22.5+$ \\
\hline 3 & 63 & $\mathrm{~F}$ & $\mathrm{LC}$ & $\begin{array}{l}\text { Uncon- } \\
\text { firmed }\end{array}$ & IA 2 & Unknown & Re-biopsy & Operable & Yes & $\begin{array}{c}\text { Lobectomy } \\
\text { (Adeno, } \\
\text { pStage IA1) }\end{array}$ & $26.3+$ & $26.3+$ \\
\hline 4 & 80 & M & $\mathrm{LC}$ & $\mathrm{Sq}$ & IIIA & Unknown & $\begin{array}{c}\text { CRT/ } \\
\text { Chemother- } \\
\text { apy }\end{array}$ & Operable & Yes & $\begin{array}{l}\text { Lobectomy } \\
\text { (LCNEC, } \\
\text { pStage IIIA) }\end{array}$ & 8.7 & $9.9+$ \\
\hline 5 & 62 & F & $\mathrm{LC}$ & $\begin{array}{l}\text { Uncon- } \\
\text { firmed }\end{array}$ & IA1 & Unknown & Re-biopsy & Operable & Yes & $\begin{array}{l}\text { Lobectomy } \\
\text { (Adeno, } \\
\text { pStage IA1) }\end{array}$ & $21.6+$ & $21.6+$ \\
\hline 6 & 61 & $\mathrm{~F}$ & $\mathrm{LC}$ & $\begin{array}{l}\text { Uncon- } \\
\text { firmed }\end{array}$ & IA 2 & Unknown & Re-biopsy & Operable & Yes & $\begin{array}{c}\text { Segmentectomy } \\
\text { (Adeno, } \\
\text { pStage IA1) }\end{array}$ & $15.0+$ & $15.0+$ \\
\hline 7 & 84 & M & $\mathrm{LC}$ & $\begin{array}{l}\text { Uncon- } \\
\text { firmed }\end{array}$ & IIIB & Unknown & BSC & Operable & Yes & $\begin{array}{c}\text { Segmentectomy } \\
\text { (Adeno, } \\
\text { pStage IA2) }\end{array}$ & $20.3+$ & $20.3+$ \\
\hline 8 & 41 & $\mathrm{~F}$ & $\mathrm{LC}$ & $\begin{array}{l}\text { Uncon- } \\
\text { firmed }\end{array}$ & IA1 & Unknown & $\begin{array}{l}\text { Observa- } \\
\text { tion }\end{array}$ & Operable & No & Unknown & Unknown & Unknown \\
\hline 9 & 63 & M & TET & $\begin{array}{l}\text { Uncon- } \\
\text { firmed }\end{array}$ & $\begin{array}{l}\text { Masa- } \\
\text { oka I }\end{array}$ & Unknown & $\begin{array}{l}\text { Observa- } \\
\text { tion }\end{array}$ & Operable & No & Unknown & Unknown & Unknown \\
\hline 10 & 87 & F & $\mathrm{LC}$ & $\begin{array}{l}\text { Uncon- } \\
\text { firmed }\end{array}$ & IA1 & Unknown & $\begin{array}{l}\text { Observa- } \\
\text { tion }\end{array}$ & Operable & No & Unknown & Unknown & Unknown \\
\hline 11 & 74 & M & LC & Adeno & IIB & Unknown & $\mathrm{RT}$ & Operable & No & Unknown & Unknown & Unknown \\
\hline 12 & 84 & M & $\begin{array}{l}\text { Pleural } \\
\text { meso- } \\
\text { thelioma }\end{array}$ & Epithelial & IA & Unknown & $\begin{array}{l}\text { Chemother- } \\
\text { apy }\end{array}$ & Operable & No & Unknown & Unknown & Unknown \\
\hline
\end{tabular}

M: male, LC: lung cancer, CCRT: concurrent chemoradiation therapy, F: female, Sq: squamous cell carcinoma, TET: thymic epithelial tumor, LCNEC: large-cell neuroendocrine carcinoma, BSC: best supportive care, Adeno: adenocarcinoma, RT: radiation therapy, + : ongoing (data cut-off April 30, 2021).

セカンドオピニオンの希望者としては，患者が 464 人 (85.9\%)，紹介医が 61 人 $(11.3 \%)$ であった。受診の夕イ ミングは，未治療が 226 人 $(41.9 \%)$ ，一次治療中が 154 人 $(28.5 \%)$, 二次治療以降が 160 人 $(29.6 \%)$ であった (Table 1). また非小細胞癌のうち 77 例が早期/局所進行 期で, 264 例が進行再発期であった.

進行期の非小細胞肺癌の治療方針を決定する際に必要 な遺伝子変異検査および PD-L1 検査の詳細については, 進行・再発非扁平上皮癌 225 人のうち, ドライバー遺伝 子検査 (EGFR, ALK, ROS1) と PD-L1 発現検査が, セカ ンドオピニオン時に施行されていたのが 114 人 $(50.7 \%)$, 検查中が 22 人 $(9.8 \%)$ であった。また組織採取不能例や 提出したが判定不能例を含む検查不十分例は 89 人 (39.6\%) であった. 進行・再発扁平上皮癌 39 人において は，PD-L1 発現検査が 23 人 $(59.0 \%)$ で検査されていた が， 2 人 $(5.1 \%)$ が検査中， 14 人 $(35.9 \%)$ が検査不十分
もしくは不明であった（Figure 1).

セカンドオピニオンの内容については, 主治医の治療 方針に変更が提案されなかったのが 393 人 $(72.8 \%)$, 治 療方針の変更が提案されたのが 147 人 $(27.2 \%)$ であった (Figure 2). 治療方針変更の内訳としては, 化学療法レジ メンの変更が 51 人 $(34.7 \%)$, best supportive care (BSC) の提案が 28 人 (19.0\%) であった. また BSCより化学療 法への変更が 24 人 $(16.3 \%$ ) (Table 2$)$, 化学放射線療法や 全身化学療法から手術切除可能と判断されたのが 12 人 (8.2\%) (Table 3), 全身化学療法から根治的照射可能な化 学放射線療法が提案されたのが 7 人 (4.8\%) であった. 新たに根治治療が提示された 19 人のうち, 11 人が国立 がん研究センター中央病院へ転院となり, そのうち 8 人 で手術治療または化学放射線療法が行われた. 残りの 3 人は, 転院時に増悪を認め, 化学療法が施行された。 セ カンドオピニオンの段階で, 診断・治療方針決定に追加 


\section{Designated cancer hospital $(\mathrm{N}=347)$}

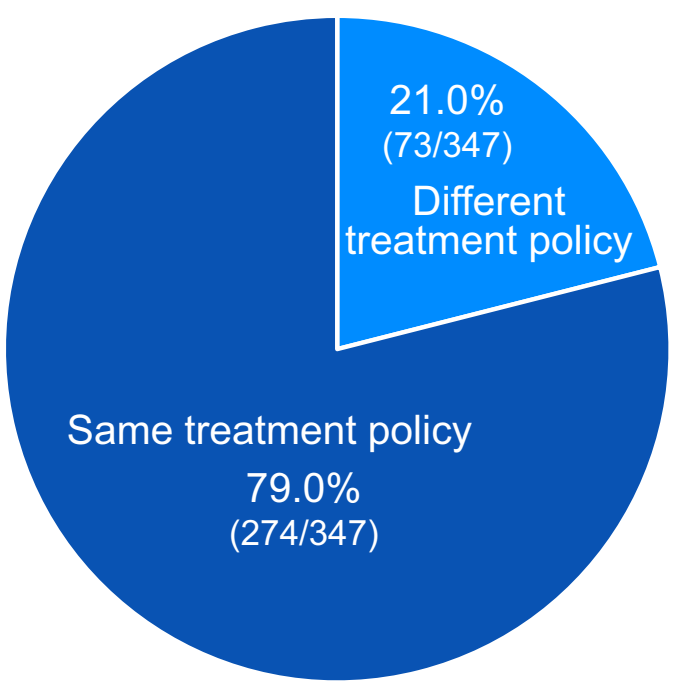

\section{Non-designated cancer hospital $(\mathrm{N}=157)$}

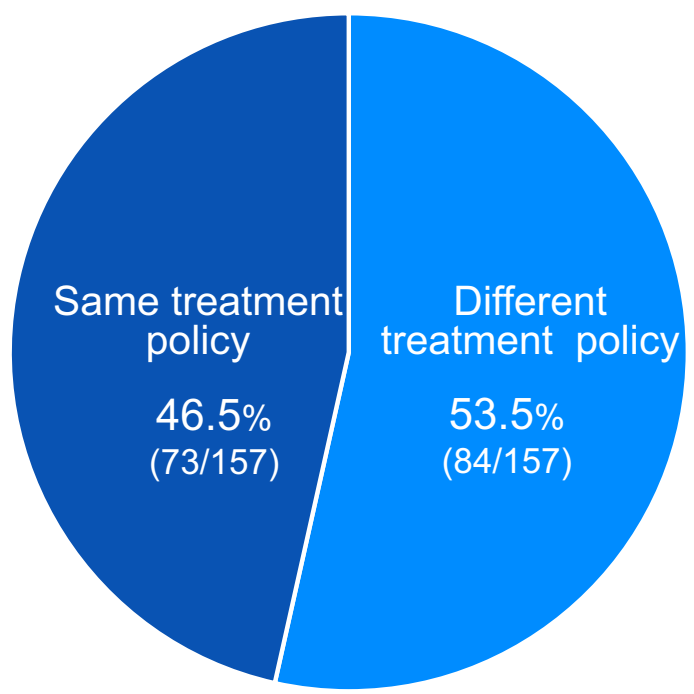

Figure 3. Rate of different treatment advice at the second opinion according to the referral hospital (designated cancer hospital vs. non-designated cancer hospital) $(\mathrm{N}=504)$.

精査が必要とされたのが 10 人 $(6.8 \%)$ であった。紹介元 の病院で参加できない治験への参加を提案した患者は 9 人 $(6.1 \%)$ であった.

紹介元の病院ごとに，治療方針の変更を提案した割合 を検討すると，海外からの患者を除いた 504 人のうち， がん拠点病院からの紹介患者はそれ以外と比較すると, 有意に治療方針の変更が少なかった（がん拠点病院： $21.0 \%$ vs. がん拠点病院以外：53.5\%, p<0.01) (Figure 3). 一方で BSC の提案の一致率については, がん拠点病 院からの紹介患者 $(44 / 63$ 人) とそれ以外 $(18 / 26$ 人) で, 有意な差は認めなかった（がん拠点病院：69.8\% vs. がん 拠点病院以外 : $69.2 \%, \mathrm{p}=1.00)$.

セカンドオピニオン後の治療場所については，がん拠 点病院からの紹介は 41 人 $(11.8 \%)$ が，がん拠点病院以 外からの紹介は 32 人 $(20.4 \%)$ が, 国立がん研究センター 中央病院で治療を受けることになった。内訳としては, 治験への参加や化学放射線療法, 手術療法など積極的治 療を提案された患者が 22 人であった.

\section{考察}

セカンドオピニオンは, 患者が検查, 診断および治療 を受けるにあたって主治医以外の医師に求めた「意見」, または「意見を求める行為」と考えられている. しかし 一方で, 検査, 診断および治療方針を病状説明する際に, 複数の選択肢があるなどの理由で, 医療者側も必ずしも
満足のいく提案が出せないことも少なくない. 実際に, 当院のセカンドオピニオンの希望者は, 患者がほとんど であったが, 医師も $11.3 \%$ となっていた。医療者側とし ても, 診療経験のそしさから診断, 明確な治療方針を判 断することが困難な場合には, 医療提供者側からセカン ドオピニオンを薦めることも少なくない. そのためセカ ンドオピニオンは, 患者と患者家族だけではなく, 医療 者側にとっても診断や治療方針の決定に際して, 有用な 選択肢の一つとなり得る。

これまで胸部悪性腫瘍領域に関するセカンドオピニオ ンの意義の報告はなかったが, 今回, 国立がん研究セン ター中央病院呼吸器内科のセカンドオピニオン外来に受 診した胸部悪性腫瘍患者を対象として後ろ向きに調査を 行い, $27.2 \%$ において主治医と異なった診断や治療方針 が提案されていた. 乳癌領域では, セカンドオピニオン によって, 16.4〜 25.1\%の患者で紹介元と異なった診断お よび治療方針が提案されたと報告されているが，本研究 では胸部悪性腫瘍領域のセカンドオピニオンにおいて, 診断および治療方針の変更の提案が他癌種より多くみら れた。 その理由としては, 非小細胞肺癌の治療方針を決 定する際には，遺伝子変異に基づく個別化治療が一般的 となっていること, 細胞障害性抗癌剤, 分子標的治療薬, 免疫チェックポイント阻害剤などの承認薬剤が多いな ど, 治療体系が複雑化し, 診療経験の少なさから治療方 針に迷い, 判断ができなくなっていることが一因となっ 
ている可能性がある.

実際, 非小細胞肺癌の治療方針を決定する際に重要な 遺伝子変異の検索については, セカンドオピニオン受診 時には約 4 割のケースで検査不十分な結果となっている とともに，治療方針の変更提案の内訳としても，化学療 法レジメン変更の提案が最も多い結果となっていた（51 人 $34.7 \%)$. 変更の提案を行った理由としては, 肺癌診療 ガイドラインに沿った治療ではないことが最も多かった $(25 / 51$ 人 $49.0 \%)$.

化学療法の変更以外にも, 根治を目指すための手術お よび化学放射線療法の提案も少なからずみられた（19 人 $12.9 \%)$ ，肺癌治療は，薬物療法だけではなく，手術お よび放射線治療の組み合わせによる集学的治療が必要と される場合が多いが，実際に手術や放射線治療など自施 設で治療が完結できない施設も少なくない. そのため, 院内カンファレンスなどでも判断に苦慮されている症例 もセカンドオピニオンに受診されていた.

本検討では，紹介元の違いによる治療方針の変更を提 案した割合が, がん拠点病院からの紹介患者では, その 他の患者と比較して有意に少ない結果であった。この理 由としては, がん診療の経験の差が影響している可能性 が考えられる。がん拠点病院の指定要件には, 集学的治 療が提供できることや多職種, 診療科が一堂に会して治 療方針を協議するキャンサーボードの開催が含まれてい る.そのためがん拠点病院では, 集学的治療の各分野の 専門医や多職種が連携し，適切な手段での治療が検討さ れていることが多く，このことが治療方針の変更の提案 が少なかった要因と考えられる。
最後に, 治療体系が複雑化している非小細胞肺癌をは じめとした胸部悪性腫瘍領域において, 適切な検査, 診 断および治療方針の決定が重要となってきている. 一方 で高齢者など遠方のがん専門病院への定期的な受診が困 難ながん患者も少なくないため, 地域での医療の完結を 目指すことが非常に重要となっている. そのためセカン ドオピニオンは, がん診療連携拠点病院などがん専門病 院に受診が困難な患者においても積極的に行うことで, 医療者側としては自施設の治療方針の確認, 患者側とし ては病態や治療方針の理解や納得度が哚まるなど, 臨床 的な意義を有する.

本論文内容に関連する著者の利益相反：なし

\section{REFERENCES}

1. Clauson J, Hsieh YC, Acharya S, Rademaker AW, Morrow M. Results of the Lynn Sage Second-Opinion Program for local therapy in patients with breast carcinoma. Changes in management and determinants of where care is delivered. Cancer. 2002;94:889-894.

2. Maruzzo M, La Verde N, Russo A, Marchetti P, Scagnoli $\mathrm{S}$, Gonzato O, et al. Second medical opinion in oncological setting. Crit Rev Oncol Hematol. 2021;160:103282.

3. Cecon N, Hillen MA, Pfaff H, Dresen A, Groß SE. Why do newly diagnosed breast cancer patients seek a second opinion? - Second opinion seeking and its association with the physician-patient relationship. Patient Educ Couns. 2019;102:998-1004.

4. Mellink WA, Henzen-Logmans SC, Bongaerts AH, Ooijen BV, Rodenburg CJ, Wiggers TH. Discrepancy between second and first opinion in surgical oncological patients. Eur J Surg Oncol. 2006;32:108-112. 